\title{
Hydrogeology of the Cascade Springs Area near Tullahoma, Tennessee
}

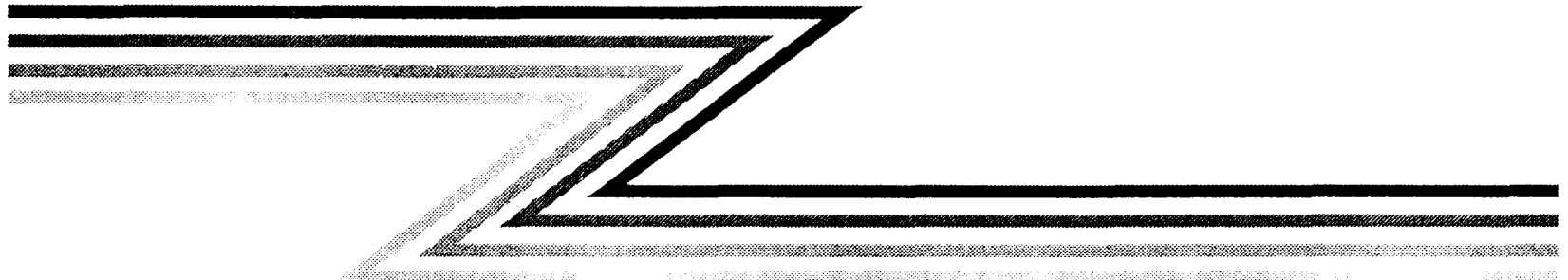

Prepared by the

U.S. Geological Survey

in cooperation with the

THE TOWN OF WARTRACE, TENNESSEE

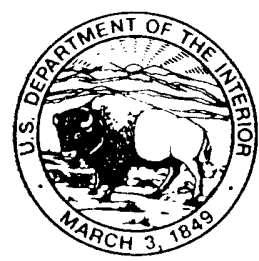




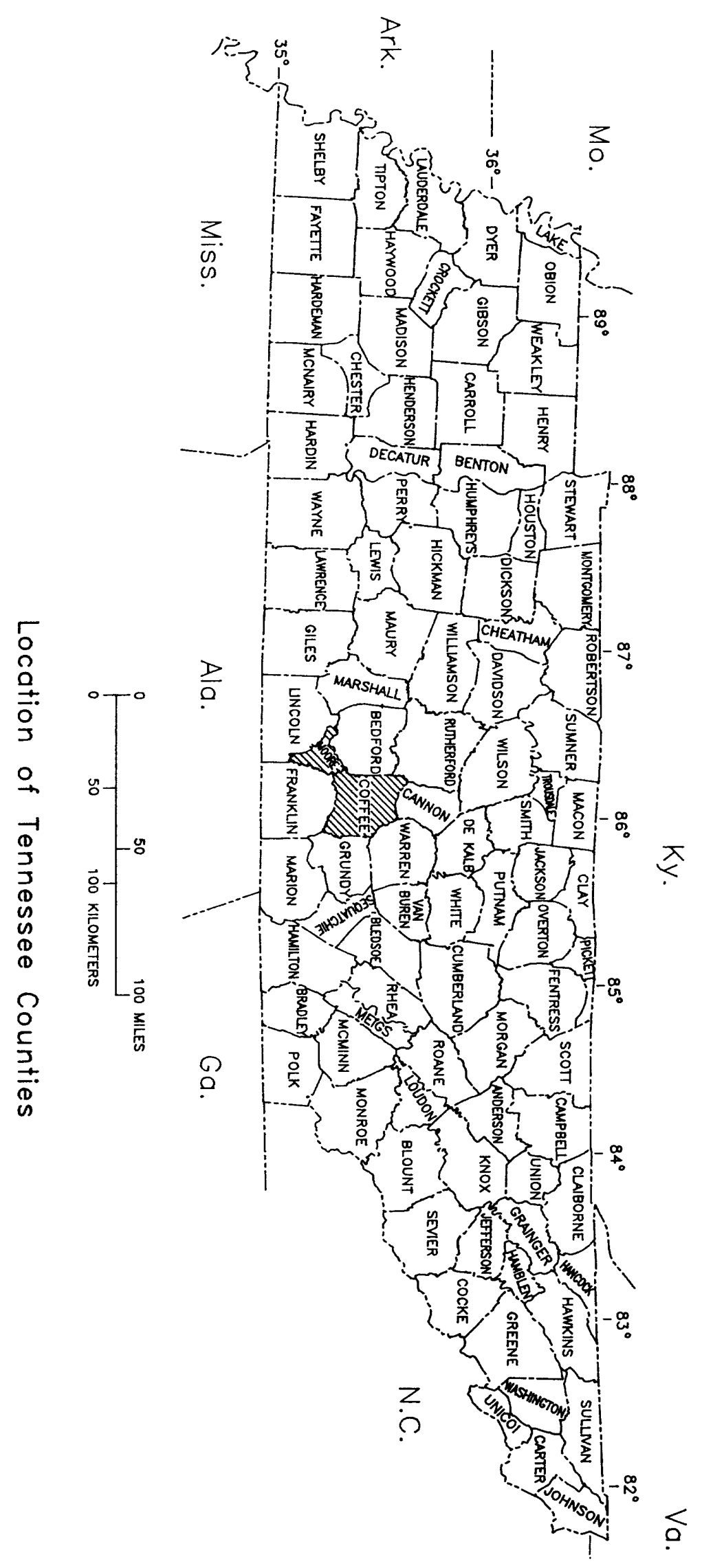




\section{Hydrogeology of the Cascade Springs Area near Tullahoma, Tennessee}

\section{By STEPHANIE E. JOHNSON}

\section{U.S. GEOLOGICAL SURVEY}

Water-Resources Investigations Report 95-4002

Prepared in cooperation with the

THE TOWN OF WARTRACE, TENNESSEE

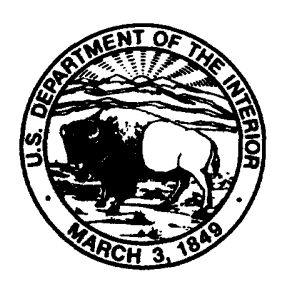

Nashville, Tennessee 1995 


\title{
U.S. DEPARTMENT OF THE INTERIOR \\ BRUCE BABBITT, Secretary
}

\author{
U.S. GEOLOGICAL SURVEY
}

Gordon P. Eaton, Director

For additional information write to:

District Chief

U.S. Geological Survey

810 Broadway, Suite 500

Nashville, Tennessee 37203
Copies of this report can

be purchased from:
U.S. Geological Survey
Earth Science Information Center
Open-File Reports Section
Box 25286, MS 517
Denver Federal Center
Denver, Colorado 80225 


\begin{tabular}{rll}
\hline Multiply & By & To obtain \\
inch (in.) & 25.4 & millimeter \\
inch per year (in/yr) & 2.54 & centimeter per year \\
foot (ft) & 0.3048 & meter \\
mile (mi) & 1.609 & kilometer \\
square mile (mi $\left.{ }^{2}\right)$ & 2.590 & square kilometer \\
gallon per minute $\left(\mathrm{gal} / \mathrm{min}^{2}\right)$ & 0.06308 & liter per second \\
microsiemens per centimeter & 1 & micromoho per centimeter \\
at $25^{\circ} \mathrm{C}(\mu \mathrm{S} / \mathrm{cm})$ & & at $25^{\circ} \mathrm{C}$
\end{tabular}

Sea Level: In this report "sea level" refers to the National Geodetic Vertical Datum of 1929--a geodetic datum derived from general adjustment of the first-order level nets of the United States and Canada, formerly called "Sea Level Datum of 1929." 


\section{CONTENTS}

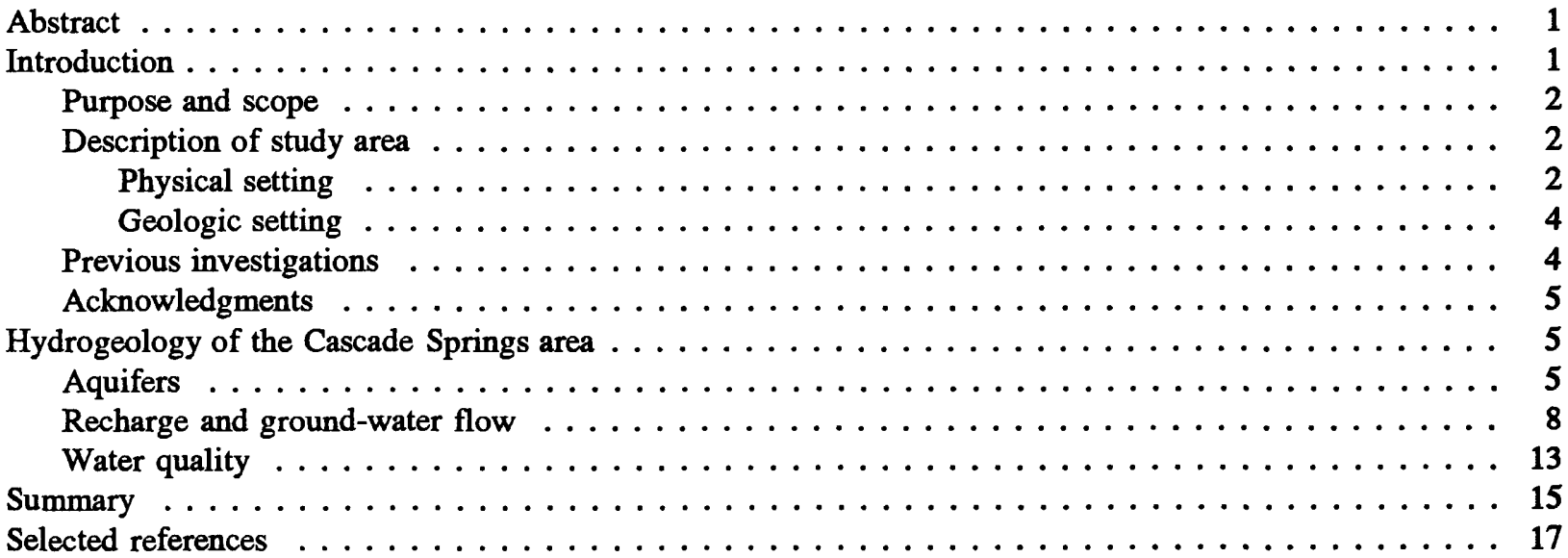

\section{FIGURES}

1. Map showing location of the Cascade Springs study area and the Highland Rim escarpment . . . . 3

2. Generalized west-east geologic section of the Cascade Springs area near Tullahoma, Tennessee (trace of section A-A' shown on figure 1) . . . . . . . . . .

3. Generalized lithology, stratigraphy, and hydrogeology of the Cascade Springs study area near Tullahoma, Tennessee, with conceptual model of ground-water flow, modified from Burchett, $1977 \ldots \ldots \ldots \ldots \ldots \ldots$

4. Caliper and natural gamma geophysical logs from well 37a at Cascade Springs near Tullahoma, Tennessee $\ldots \ldots \ldots \ldots \ldots \ldots \ldots \ldots \ldots \ldots$

5-7. Maps showing:

5. Location of wells used for water-level measurements in the Cascade Springs study area . . . . . 9

6. Potentiometric surface of the Manchester aquifer for April 1992 and approximate boundary ... of the Cascade Springs recharge area $\ldots \ldots \ldots \ldots \ldots \ldots \ldots \ldots \ldots \ldots \ldots$

7. Potentiometric surface of the Fort Payne aquifer for April $1992 \ldots \ldots \ldots \ldots \ldots \ldots \ldots$

\section{TABLES}

1. Well-construction and water-level data for wells in the Cascade Springs study area near

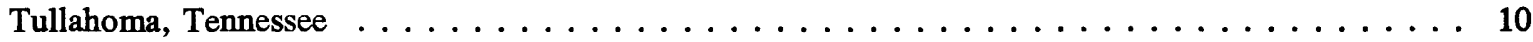

2. Water-quality data for Left Cascade Spring near Tullahoma, Tennessee . . . . . . . . . . . 14 


\section{Hydrogeology of the Cascade Springs Area near Tullahoma, Tennessee}

By Stephanie E. Johnson

\section{Abstract}

The ground-water-flow system contributing to Cascade Springs near Tullahoma, Tennessee, was investigated from September 1991 to May 1992. Cascade Springs, consisting of Left Cascade and Right Cascade Springs, are located on the escarpment of the Highland Rim and discharge immediately above the Chattanooga Shale from the cherty Fort Payne Formation. Left Cascade Spring is the sole source of water for the Town of Wartrace and for a local whiskey distillery.

Two major aquifers, the Manchester and the Fort Payne aquifers, contribute groundwater flow to Cascade Springs. The Manchester aquifer is composed of unconsolidated chert gravel with minimal clay content and the upper, well-fractured interval of the Fort Payne Formation. The Fort Payne aquifer consists of dense, bedded, cherty limestone with few fractures. Where present, the fractures of the Fort Payne aquifer are concentrated immediately above the Chattanooga Shale along horizontal bedding planes.

The Manchester and the Fort Payne aquifers are hydraulically connected. However, the dense cherty limestone of the Fort Payne Formation, where unfractured, can impede the downward flow of ground water from the Manchester aquifer. Near the Highland Rim escarpment, as a result of this local confinement, the potentiometric head of wells completed in the Manchester aquifer is
36- to 80-feet higher than the head of wells completed in the Fort Payne aquifer.

The primary recharge area for Cascade Springs is located southeast of the springs. The estimated recharge area for the Manchester aquifer encompasses approximately 1 square mile. The lateral extent of the recharge area for the Fort Payne aquifer cannot be delineated because few wells completed in the Fort Payne aquifer are located southeast of Cascade Springs.

The water quality of Left Cascade Spring is dominated by calcium and bicarbonate ions with low concentrations of inorganic constituents and dissolved solids. Two volatile organic compounds (1.3 micrograms per liter of 1,2-transdichloroethene and 0.2 micrograms per liter of trichloroethylene) were detected in a recent analysis of water from Left Cascade Spring.

\section{INTRODUCTION}

Cascade Springs, two distinct springs of approximately equal discharge, are located 3.5 miles north of Tullahoma in western Coffee County, Tennessee. Right Cascade Spring is unused, but Left Cascade Spring is the sole source of water for the Wartrace Water System. In 1989 the Wartrace Water System supplied 0.52 million gallons of water per day to the Town of Wartrace, 14 miles northwest of Tullahoma, and to a local whiskey distillery (Hutson, 
1991). Nevertheless, little was known about the recharge area of the springs, the characteristics of the local aquifers, or the water quality of the springs. Historical discharge data for the springs were also minimal. A recent water-quality analysis of Left Cascade Spring detected low concentrations of two volatile organic compounds and raised concerns about possible nonpointsource pollution to the recharge area of the spring.

The U.S. Geological Survey (USGS), in cooperation with the Town of Wartrace, conducted a hydrogeologic investigation of the Cascade Springs area from September 1991 to May 1992. The objectives of the investigation were to describe the hydrogeology of the Cascade Springs area, to identify the recharge area of the springs, and to describe the water quality.

\section{Purpose and Scope}

This report presents the results of the hydrogeologic investigation of the Cascade Springs area. Topics discussed include:

- aquifers in the study area,

- the potentiometric surface of two major aquifers in the Cascade Springs area,

- recharge areas and ground-water flow, and

- the water quality of Left Cascade Spring.

Hydrogeologic data collected during this study included water-level measurements at 41 domestic wells. Water-levels were measured in October 1991, during low water-table conditions, and in February and April 1992, during high water-table conditions. Most of the wells measured were located within a 2-mile radius of the springs, although additional water-level measurements were made throughout the study area. Natural gamma-ray and caliper geophysical logs were also run in 3 of the 41 domestic wells. Because the Chattanooga Shale is considered a regional confining unit, only the aquifers above the Chattanooga Shale were studied for this investigation. The discussion of water quality of Left Cascade Spring is based on three water samples collected before this investigation.

\section{Description of Study Area}

The Cascade Springs study area encompasses approximately $21 \mathrm{mi}^{2}$ in Coffee and Moore Counties (fig. 1). The study area is bordered to the north by Normandy Lake and the Duck River and to the east by Carroll Creek. The southern boundary of the study area runs through the city of Tullahoma, extending approximately 3 miles west of the city. The lower reach of Norman Creek forms the northwestern boundary. Tullahoma, population 18,500 , is a major business and residential center in the area. Land use west and north of Tullahoma is mostly rural residential.

\section{Physical Setting}

Left and Right Cascade Springs discharge at an altitude of approximately 990 feet above sea level from the escarpment of the Highland Rim. The steeply sloped escarpment, which borders the study area on three sides, separates two physiographic provinces: the Central Basin to the northwest of the study area and the Highland Rim to the southeast. The Central Basin is mostly flat to gently rolling with occasional high knobs formed by remnants of the Highland Rim. In the study area, the Highland Rim lies more than 200 feet above the Central Basin, at an altitude of about 1,070 feet. Atop the Highland Rim, the terrain is flat to gently rolling with poorly defined stream channels. West of Tullahoma, the dense soil of the Highland Rim is poorly drained, resulting in a wetland area known as the Barrens.

Left Cascade Spring, one of many springs which discharge along the escarpment of the Highland Rim, has been used as a public water supply since the early 1950's. Nevertheless, few discharge measurements exist for Cascade Springs. In 1933, Left and Right Cascade Springs had a combined discharge of approximately $1,500 \mathrm{gal} / \mathrm{min}$ after a 60 -day period of little or no rainfall (Burchett, 1977). A discharge of $1,700 \mathrm{gal} / \mathrm{min}$ was measured by the USGS in October 1962 for Left Cascade Spring, and $785 \mathrm{gal} / \mathrm{min}$ was measured for Right Cascade Spring in September 1964. 


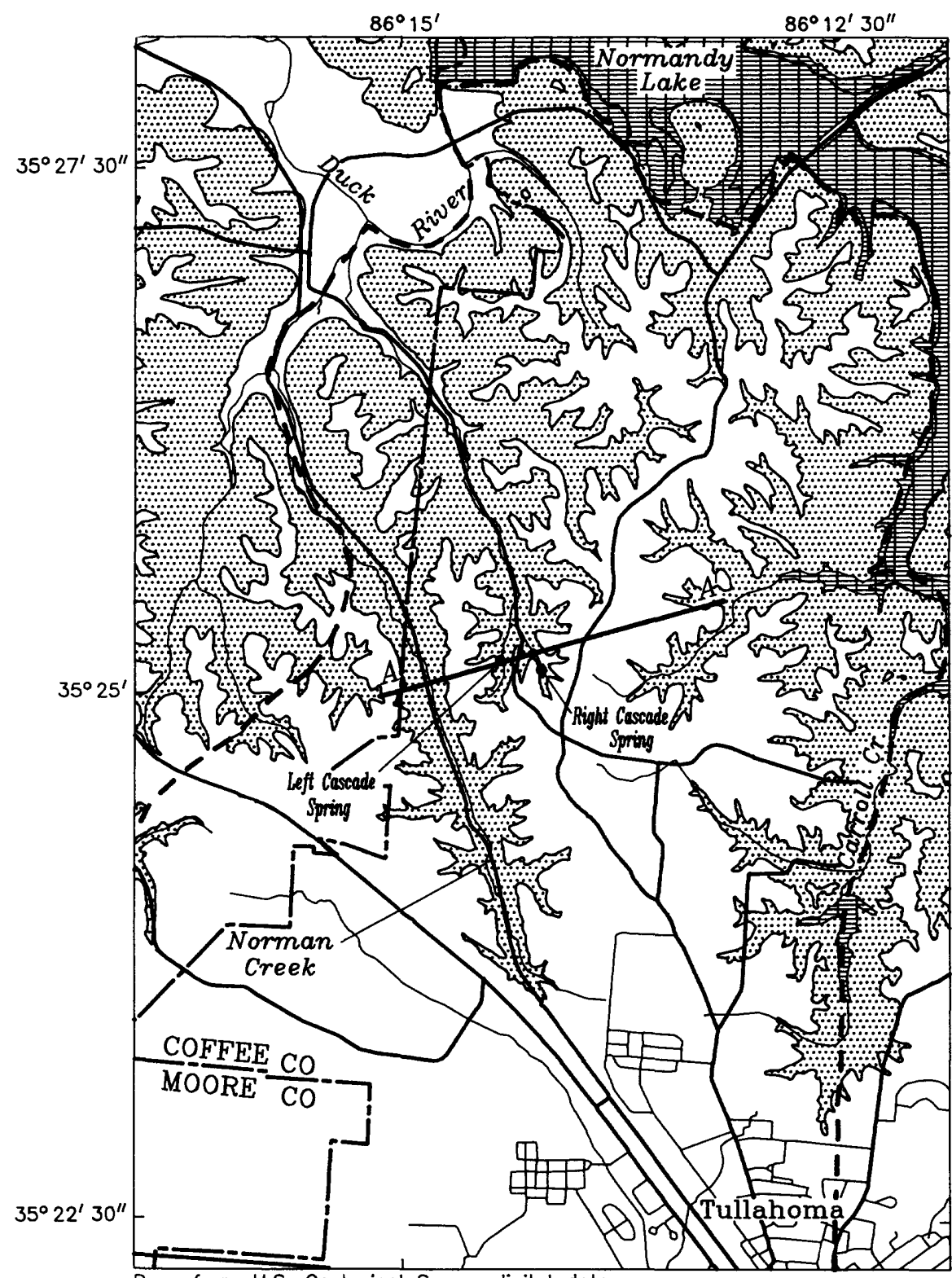

Base from U.S. Geological Survey digitol dato

$1: 100,000,1983$

Universol Tronsverse Mercotor projection

Zone 16

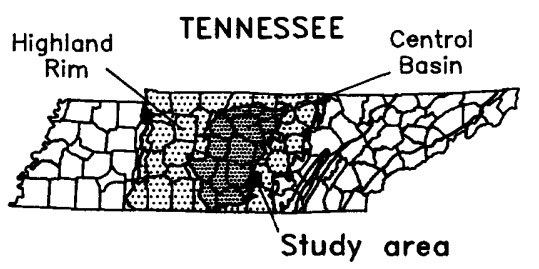

EXPLANATION
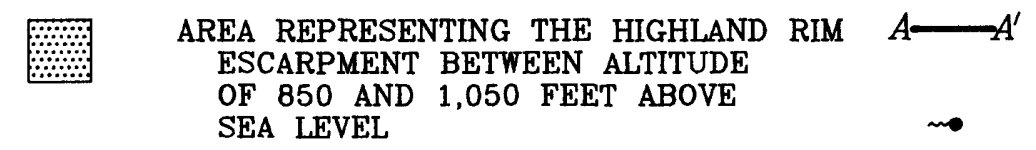

LINE OF GEOLOGIC SECTION--Section shown in figure 2

SPRING

- - BOUNDARY OF THE CASCADE SPRINGS STUDY AREA

Figure 1. Location of the Cascade Springs study area and the Highland Rim escarpment. 
The Cascade Springs study area receives a mean annual rainfall of $54.7 \mathrm{in} / \mathrm{yr}$. The largest mean monthly rainfall occurs during December through March; the least occurs from August through October (National Oceanic and Atmospheric Administration, 1980).

\section{Geologic Setting}

In the Cascade Springs study area, Wilson $(1970 \mathrm{a}, \mathrm{b})$ identified five formations within 200 feet of land surface on the Highland Rim. These are the undifferentiated Leipers and Catheys Formations of Ordovician age, the Chattanooga Shale of Upper Devonian to Lower Mississippian age, and the Fort Payne and Warsaw Formations of Mississippian age (fig. 2). These formations are mostly flat-lying. The Leipers and Catheys Formations consist of 70 to 90 percent calcium carbonate and are easily weathered and contain numerous caves and solution cavities (Burchett, 1977). The Chattanooga Shale is a fissile, grey-black, carbonaceous shale, approximately 30 feet thick in the study area.

The Fort Payne Formation is a siliceous limestone containing dense chert beds. On the Highland Rim, the Fort Payne Formation contains less than 50 percent calcium carbonate. The upper, weathered section of the Fort Payne Formation exists as chert gravel and rubble. This residuum ranges in thickness from less than 20 feet at a distance of 4 to 6 miles away from the Highland Rim escarpment to 100 feet near the edge of the escarpment. The Warsaw Formation is present only in the southern end of the study area and has been completely weathered to a clay residuum (Burchett, 1977).

\section{Previous Investigations}

Wilson (1970a,b) mapped in detail the geology of the Normandy and Ovoca 7-1/2 minute quadrangles and summarized the mineral resources of those areas. Theis (1936) described the ground-water resources of south-central Tennessee. Smith (1962) outlined the groundwater resources and municipal water supplies of the Highland Rim. The water resources of the upper Duck River basin were described by Burchett (1977). Zurawski (1978) developed conceptual models of ground-water flow in the Highland Rim. Brahana and Bradley (1986)

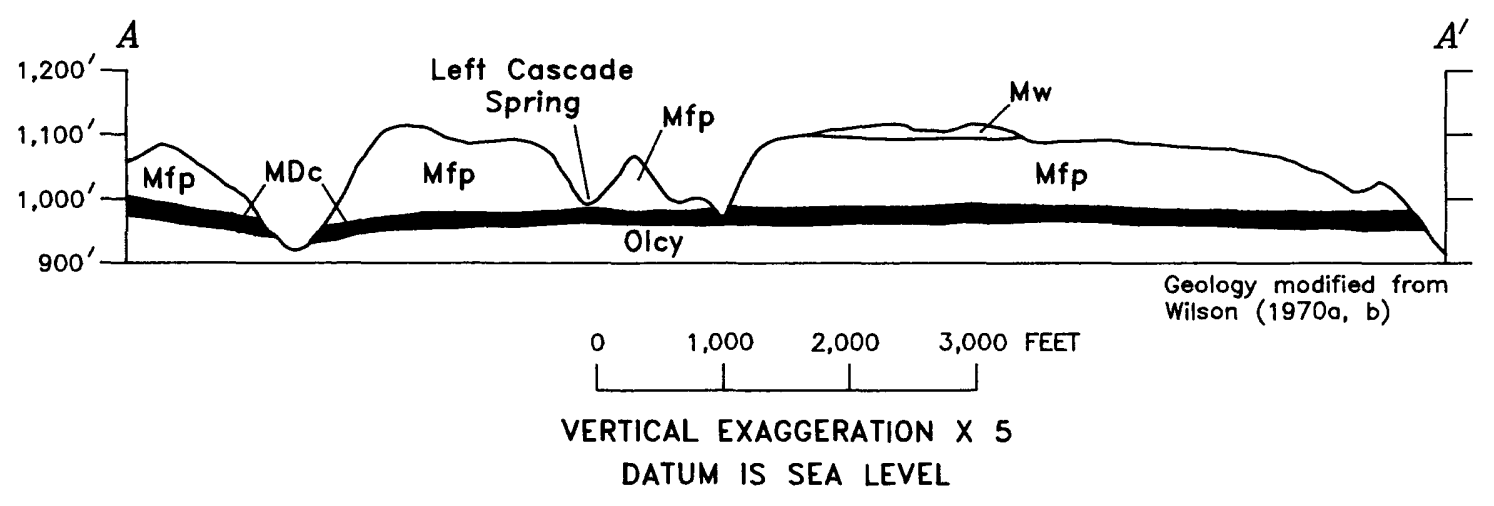

EXPLANATION

$\begin{array}{ll}\text { Mw } & \text { MISSISSIPPIAN WARSAW FORMATION } \\ \text { MfP } & \text { MISSISSIPPIAN FORT PAYNE FORMATION } \\ \text { MDc } & \text { UPPER DEVONIAN TO LOWER MISSISSIPPIAN } \\ & \text { CHATTANOOGA SHALE } \\ \text { Olcy } & \text { ORDOVICIAN LEIPERS AND CATHEYS FORMATIONS }\end{array}$

Figure 2. Generalized west-east geologic section of the Cascade Springs study area near Tullahoma, Tennessee. 
described the Highland Rim regional aquifer system. Haugh and Mahoney (1994) described the hydrogeology and water-quality of the Highland Rim aquifer system at Arnold Air Force Base.

\section{Acknowledgments}

The author expresses appreciation to the landowners in the study area for granting access to their domestic wells. Appreciation is also extended to the Coffee County School Board for assisting the geophysical logging efforts by improving access to the wells at Jones Elementary School.

\section{HYDROGEOLOGY OF THE CASCADE SPRINGS AREA}

Two regional ground-water systems exist in the Cascade Springs area: the Highland Rim aquifer system and the upper Central Basin aquifer system. These systems are separated by the Chattanooga Shale, considered a regional confining unit (Brahana and Bradley, 1986). The hydrology of the Highland Rim aquifer system in the study area is complex because the aquifers are in a highly dissected area of the Highland Rim. Springs located on the escarpment near the top of the Chattanooga Shale drain the overlying aquifers and cause steep potentiometric gradients behind the escarpment.

The upper Central Basin aquifer system, below the Chattanooga Shale, is not a productive water-bearing unit in the study area. Waterquality analyses from wells at Arnold Air Force Base, located 1 mile east of Tullahoma, indicate that ground water from the upper Central Basin aquifer system is chemically distinct and isolated from the aquifers overlying the Chattanooga Shale (Haugh and Mahoney, 1994). Because the Chattanooga Shale is considered the base of the hydrologic system of interest, only aquifers above the Chattanooga Shale are considered further in this report.

\section{Aquifers}

Two major aquifers, the Manchester and the Fort Payne aquifers, contribute ground-water flow to Cascade Springs (fig. 3). A third aquifer of minor significance in the study area overlies the Manchester aquifer. This is the shallow aquifer composed of clay, silt, sand, and some chert rubble. This unit is poorly productive and contains the water table, which is sometimes perched. Only hand-dug wells are completed in the shallow aquifer in the Cascade Springs area.

The Manchester aquifer is composed of unconsolidated well-sorted chert gravel with minimal clay content and the upper, well-fractured interval of the Fort Payne Formation that contains interconnected solution openings. The fractured bedrock in the upper Fort Payne Formation has been observed nearby at Arnold Air Force Base (E.N. Mahoney, USGS, oral commun., 1992). However, this investigation could not confirm the presence of this well-fractured interval in the Cascade Springs area. With time, the movement of ground water through the residuum has left in place a highly productive aquifer of chert gravel. Most domestic wells completed in the Manchester aquifer within the study area are screened at the residuum-bedrock contact. The Manchester aquifer is semi-confined in areas where clay and silt from the near-surface residuum above act as a leaky confining unit.

The Fort Payne aquifer consists of dense limestone and bedded chert in the Fort Payne Formation. Ground-water flow occurs primarily through secondary porosity in the limestone parts of the formation. Within half a mile of the escarpment, the Fort Payne aquifer contains solution openings along bedding planes just above the Chattanooga Shale (fig. 3), as indicated by geophysical logs. A caliper log of a well located 0.1 mile from the escarpment and 0.3 mile southeast of Right Cascade Spring shows an opening 3 feet high, which occurs approximately 10 feet above the Chattanooga Shale at that well (fig. 4). The Chattanooga Shale is indicated by 


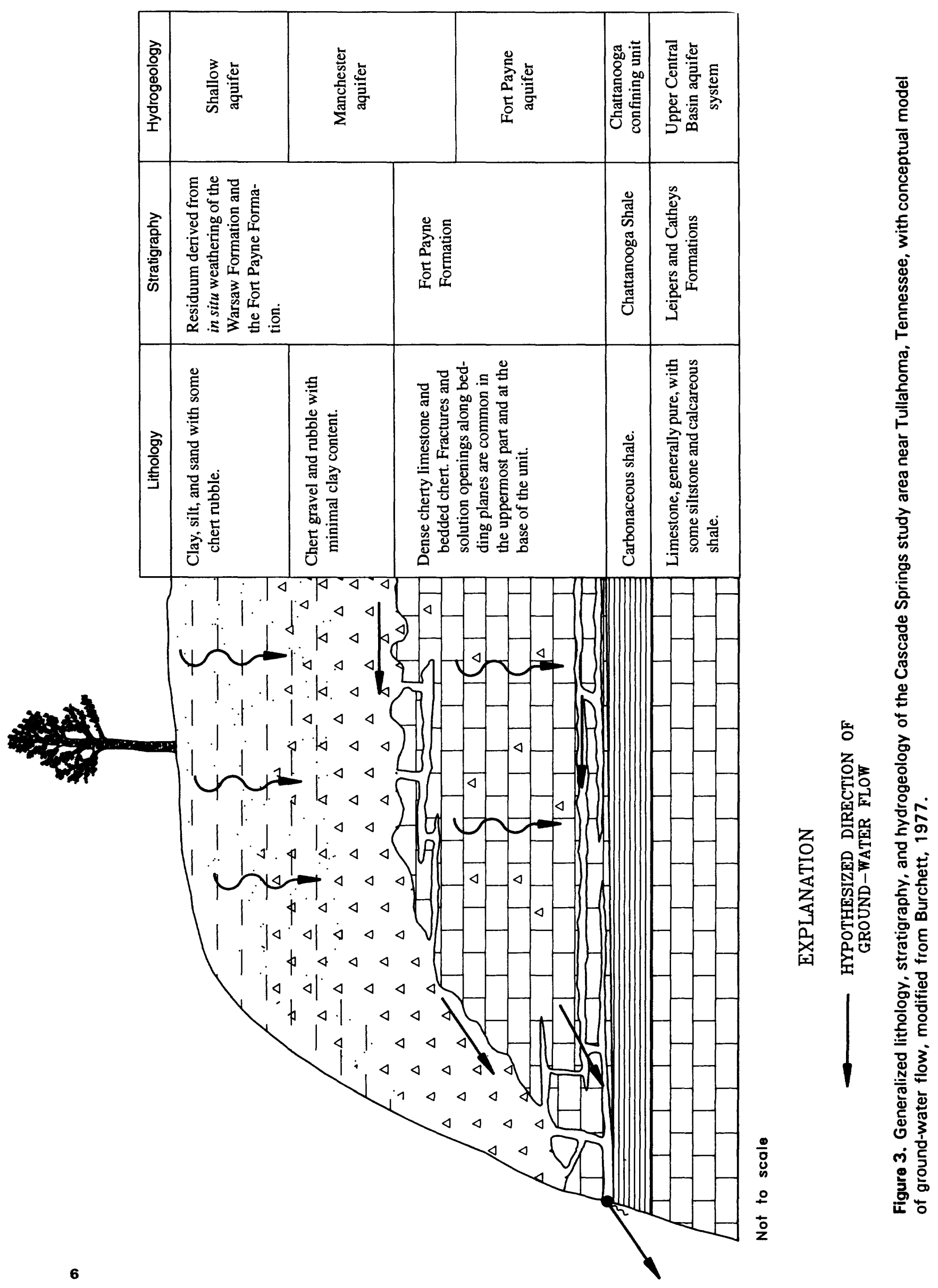




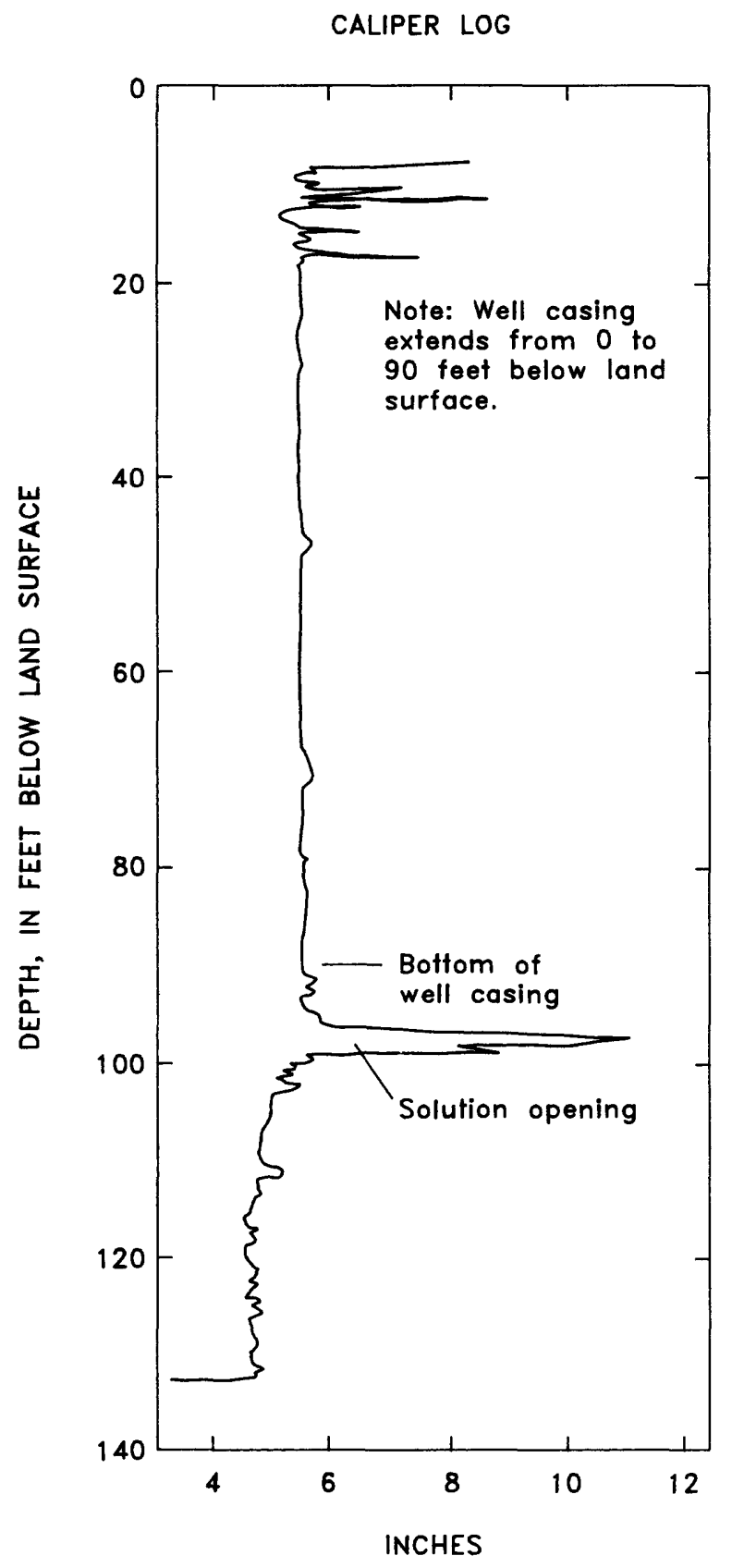

NATURAL GAMMA-RAY LOG

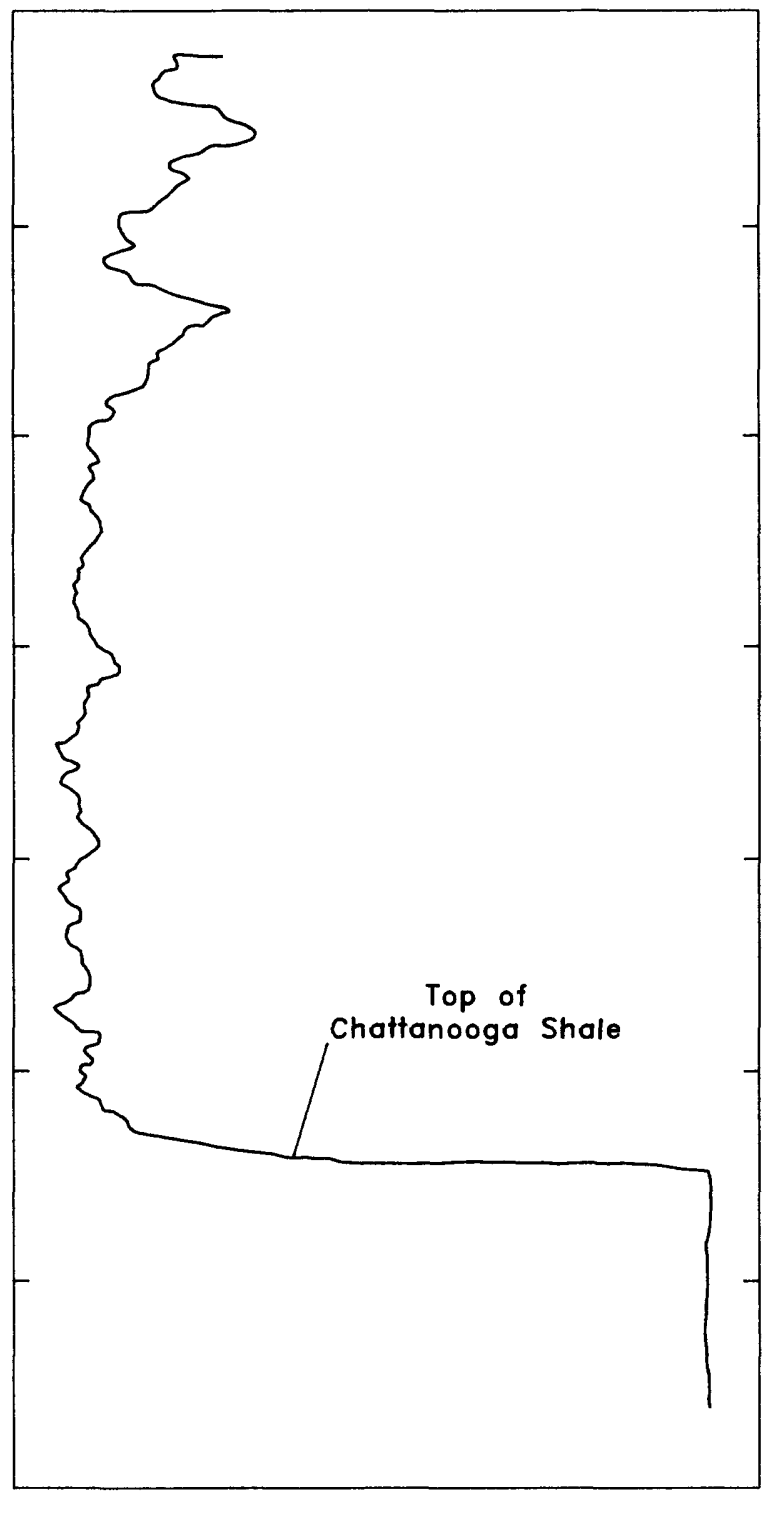

RADIOACTIVITY INCREASES

Figure 4. Caliper and natural-gamma geophysical logs from well 37a at Cascade Springs near Tullahoma, Tennessee. 
the gamma-ray log in fig. 4. Bedding-plane openings have also been observed at the discharge points of Right Cascade Spring at the contact between the Fort Payne Formation and the Chattanooga Shale. Ground water in the Fort Payne aquifer is recharged by the Manchester aquifer and discharges through springs along the Highland Rim escarpment (fig. 3).

In the study area, most domestic wells yield ground water from the Manchester aquifer at the interface between the residuum and bedrock. Based on drillers' logs from 24 wells, the waterbearing zone was reported to be at the top of bedrock in 67 percent of the wells. In 21 percent of the wells the water-bearing zone was reported to be immediately above the Chattanooga Shale in the Fort Payne aquifer. The driller's logs reported water-bearing zones at both intervals in 12 percent of the wells.

Well yields in the Cascade Springs area ranged from $1 \mathrm{gal} / \mathrm{min}$ to $60 \mathrm{gal} / \mathrm{min}$. Drillers' logs reported the greatest yields for wells completed in the Manchester aquifer. The average yield of Manchester wells was $19 \mathrm{gal} / \mathrm{min}$, whereas yields of wells completed in the Fort Payne aquifer averaged $6 \mathrm{gal} / \mathrm{min}$. For those wells screened in both aquifers, the average yield was $7 \mathrm{gal} / \mathrm{min}$.

Of 36 domestic wells for which the depth to bedrock was reported, the minimum depth was 45 feet. Average depth to bedrock was 81 feet, and west of Tullahoma and near Cascade Springs, bedrock depth exceeded 100 feet.

\section{Recharge and Ground-water Flow}

Recharge to the aquifers occurs primarily by the infiltration of precipitation. To delineate the recharge area and determine the directions of ground-water flow in the study area, water levels were measured at 41 domestic wells within a 3.5-mile radius of Left Cascade Spring (fig. 5). Water-level measurements were made in October 1991, February 1992, and April 1992 to determine the potentiometric surface altitudes and directions of ground-water flow during dry and wet periods of the year (table 1). Additional wells were located after the October 1991 waterlevel measurements to improve the data distribution. The well-construction data presented in table 1 were obtained from a combination of sources, including drillers' logs, well owners, and field inspection.

Using the April 1992 water-level data, the most comprehensive data set, two potentiometric surface maps were constructed representing the Manchester and the Fort Payne aquifers (figures 6 and 7). Although water levels were measured in 29 wells during April 1992, several measurements northeast and west of Cascade Springs were omitted from the potentiometric surface maps because of their distance from the apparent recharge area. The potentiometric surface map of the Manchester aquifer shows potentiometric highs east and southeast of Cascade Springs. A potentiometric trough, separating the highs, lies in a zone of increased residuum thickness southeast of Cascade Springs. The potentiometric surface map of the Fort Payne aquifer shows steep hydraulic gradients near the Highland Rim escarpment. The highest potentiometric heads in the Fort Payne aquifer occur southeast of Cascade Springs. The ground-water divides in the Fort Payne aquifer cannot be defined because of the limited number and inadequate distribution of wells completed in the Fort Payne aquifer.

In the Cascade Springs study area, potentiometric heads in the Manchester aquifer were generally higher in altitude than heads in the Fort Payne aquifer, indicating a recharge area. During the study, large potentiometric head differences between the two aquifers were observed along the ridge northeast of Cascade Springs and northwest of Tullahoma. In these two areas, the potentiometric heads of wells completed in the residuum of the Manchester aquifer were 36 to 80 feet higher than the heads of nearby wells completed in the Fort Payne aquifer. Such substantial potentiometric head differences are likely caused by dense, poorly fractured chert beds in the Fort Payne Formation that impede the downward flow of ground water from the 


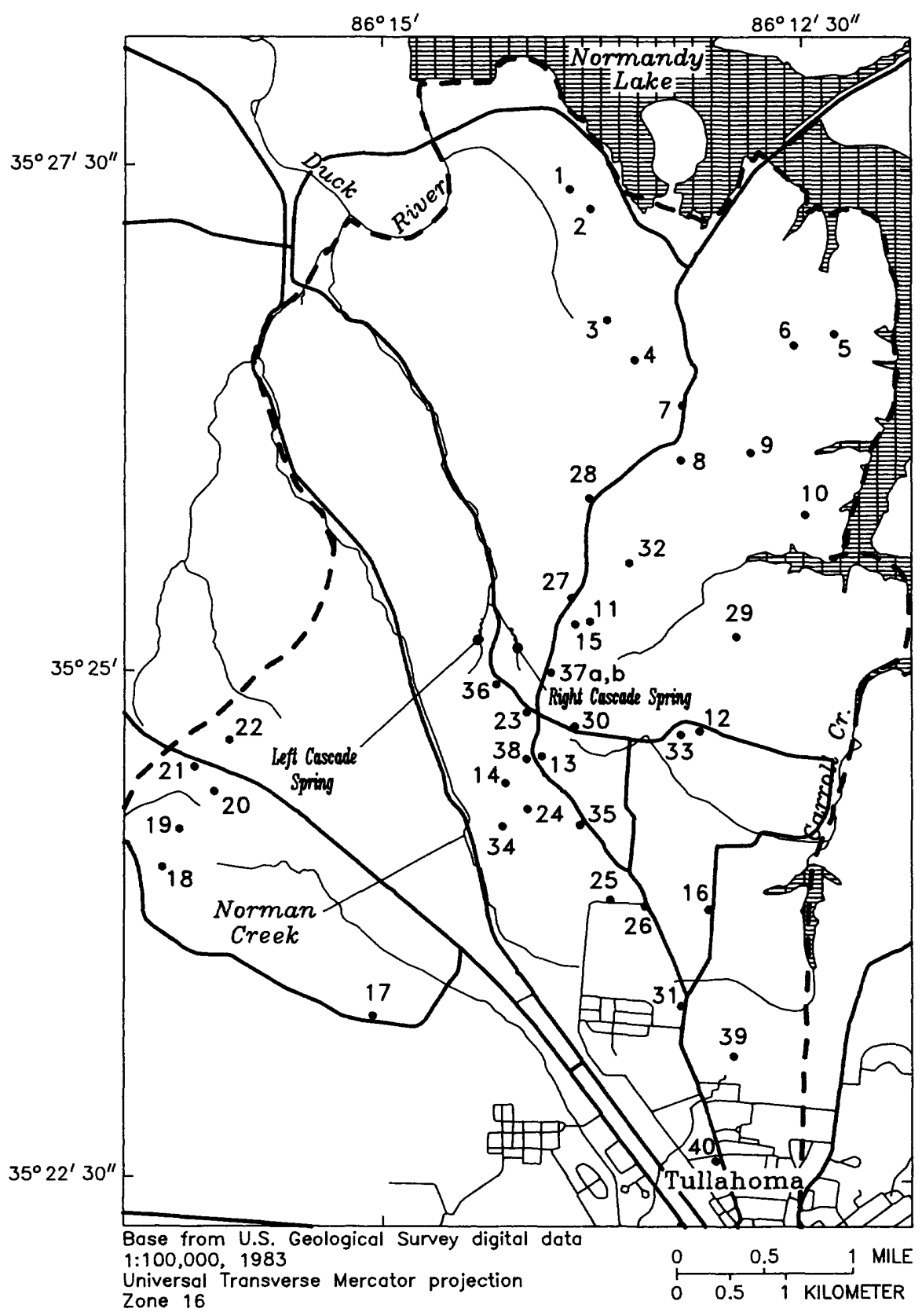

EXPLANATION

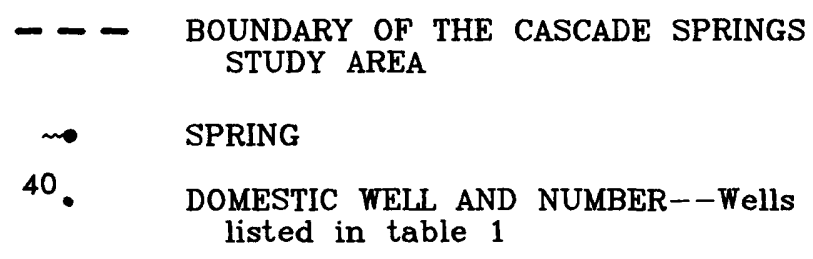

Figure 5. Location of wells used for water-level measurements in the Cascade Springs study area. 
Table 1. Well-construction and water-level data for wells in the Cascade Springs study area near Tullahoma, Tennessee

[Well depths are feet below land surface; altitudes are feet above sea level; water levels are feet below measuring point; --, no data; $>$, greater than]

\begin{tabular}{|c|c|c|c|c|c|c|c|c|c|}
\hline $\begin{array}{c}\text { Well } \\
\text { number } \\
\text { (fig. 5) }\end{array}$ & Aquifer & $\begin{array}{l}\text { Well } \\
\text { depth }\end{array}$ & $\begin{array}{l}\text { Measuring } \\
\text { point } \\
\text { altitude } \\
\text { (estimated) }\end{array}$ & $\begin{array}{c}\text { October } \\
1991 \\
\text { water } \\
\text { level }\end{array}$ & $\begin{array}{c}\text { October } \\
1991 \\
\text { potentio- } \\
\text { metric } \\
\text { surface } \\
\text { altitude }\end{array}$ & $\begin{array}{c}\text { February } \\
1992 \\
\text { water } \\
\text { level }\end{array}$ & $\begin{array}{c}\text { February } \\
1992 \\
\text { potentio- } \\
\text { metric } \\
\text { surface } \\
\text { altitude }\end{array}$ & $\begin{array}{c}\text { April } \\
1992 \\
\text { water } \\
\text { level }\end{array}$ & $\begin{array}{c}\text { April } \\
1992 \\
\text { potentio- } \\
\text { metric } \\
\text { surface } \\
\text { altitude }\end{array}$ \\
\hline 1 & Fort Payne & 160 & 1,059 & 57.5 & 1,002 & 51.75 & 1,007 & 49.16 & 1,010 \\
\hline 2 & Fort Payne & 137 & 1,081 & 67.5 & 1,014 & 63.69 & 1,017 & 63.43 & 1,018 \\
\hline 3 & Fort Payne & 103 & 1,106 & 81.8 & 1,024 & 80.96 & 1,025 & 80.91 & 1,025 \\
\hline 4 & Fort Payne & 105 & 1,095 & 96.2 & 999 & 95.73 & 999 & 95.68 & 999 \\
\hline 5 & Fort Payne & 263 & 1,072 & 84.8 & 987 & 84.33 & 988 & -- & - \\
\hline 6 & Fort Payne & 125 & 1,095 & 90.2 & 1,005 & 89.60 & 1,005 & -- & -- \\
\hline 7 & Manchester & 63 & 1,092 & 52.6 & 1,039 & 51.90 & 1,040 & 52.68 & 1,039 \\
\hline 8 & Manchester & 100 & 1,093 & 48.8 & 1,044 & 45.78 & 1,047 & 44.95 & 1,048 \\
\hline 9 & Manchester & - & 1,081 & 55.2 & 1,026 & 49.54 & 1,031 & - & -- \\
\hline 10 & Fort Payne & - & 1,042 & 68.5 & 974 & 70.00 & 972 & -- & - \\
\hline 11 & Manchester & 123 & 1,101 & 42.9 & 1,058 & 40.36 & 1,061 & 41.79 & 1,059 \\
\hline 12 & Manchester & 55 & 1,082 & 36.0 & 1,046 & 24.00 & 1,058 & 27.30 & 1,055 \\
\hline 13 & Fort Payne & 104 & 1,112 & 85.0 & 1,027 & 80.60 & 1,031 & 80.83 & 1,031 \\
\hline 14 & Fort Payne & 107 & 1,086 & 68.7 & 1,017 & 67.48 & 1,019 & 66.56 & 1,019 \\
\hline 15 & Manchester & 76 & 1,092 & - & - & -- & -- & 30.27 & 1,062 \\
\hline 16 & Manchester & - & 1,062 & 20.8 & 1,041 & - & - & - & -- \\
\hline 17 & Manchester & 88 & 1,089 & 20.7 & 1,068 & 8.54 & 1,080 & 9.90 & 1,079 \\
\hline 18 & Manchester & 105 & 1,099 & 32.6 & 1,066 & -- & -- & -- & - \\
\hline 19 & Fort Payne & 143 & 1,114 & 102.0 & 1,012 & -- & - & -- & - \\
\hline 20 & Fort Payne & - & 1,080 & 90.7 & 989 & -- & -- & - & - \\
\hline 21 & Manchester & - & 1,126 & 57.1 & 1,069 & - & - & -- & - \\
\hline 22 & Fort Payne & -- & 1,140 & 112.7 & 1,027 & - & -- & -- & -- \\
\hline 23 & Fort Payne & 113 & 1,113 & -- & -- & 101.12 & 1,012 & 100.98 & 1,012 \\
\hline 24 & Fort Payne & $>103$ & 1,083 & - & - & 60.10 & 1,023 & 59.75 & 1,023 \\
\hline 25 & Manchester & 58 & 1,077 & -- & - & 40.74 & 1,037 & 44.22 & 1,033 \\
\hline 26 & Manchester & 67 & 1,078 & - & -- & 25.13 & 1,053 & 26.61 & 1,051 \\
\hline 27 & Manchester & 100 & 1,110 & -- & - & 60.56 & 1,049 & 60.17 & 1,050 \\
\hline 28 & Manchester & 53 & 1,092 & -- & -- & 45.05 & 1,047 & 44.28 & 1,048 \\
\hline 29 & Manchester & 65 & 1,069 & - & -- & 41.77 & 1,027 & 40.72 & 1,028 \\
\hline 30 & Fort Payne & -- & 1,098 & -- & -- & 86.57 & 1,011 & 86.52 & 1,011 \\
\hline 31 & Manchester & 65 & 1,080 & -- & - & 37.68 & 1,042 & -- & -- \\
\hline 32 & Fort Payne & 91 & 1,066 & -- & - & 73.44 & 993 & 73.42 & 993 \\
\hline 33 & Manchester & 57 & 1,087 & -- & - & 25.16 & 1,062 & - & -- \\
\hline 34 & Fort Payne & 120 & 1,078 & - & - & 57.22 & 1,021 & 55.58 & 1,022 \\
\hline 35 & Manchester & 70 & 1,095 & -- & - & 61.95 & 1,033 & 60.46 & 1,035 \\
\hline 36 & Fort Payne & 136 & 1,107 & -- & -- & 103.84 & 1,003 & 103.82 & 1,003 \\
\hline $37 a$ & Fort Payne & 139 & 1,118 & -- & -- & 99.52 & 1,018 & 99.83 & 1,018 \\
\hline $37 \mathrm{~b}$ & Manchester & 73 & 1,118 & -- & -- & -- & - & 63.63 & 1,054 \\
\hline 38 & Fort Payne & 112 & 1,109 & - & -- & 85.30 & 1,024 & 85.43 & 1,024 \\
\hline 39 & Manchester & 145 & 1,067 & - & - & - & - & 35.00 & 1,032 \\
\hline 40 & Manchester & 80 & 1,066 & - & - & - & - & 37.48 & 1,029 \\
\hline
\end{tabular}




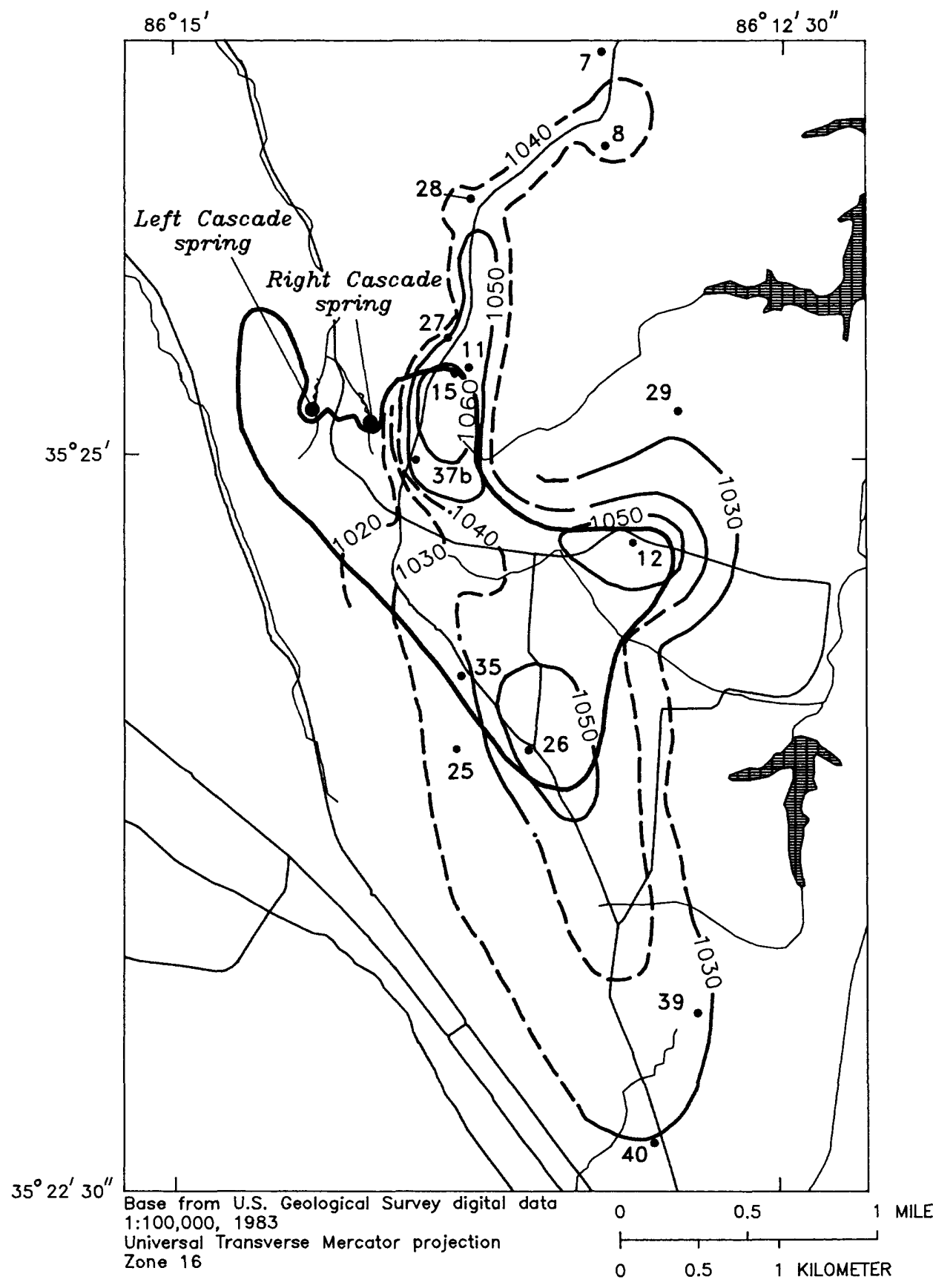

EXPLANATION

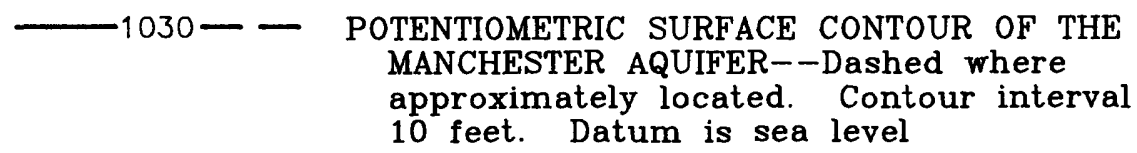

> 


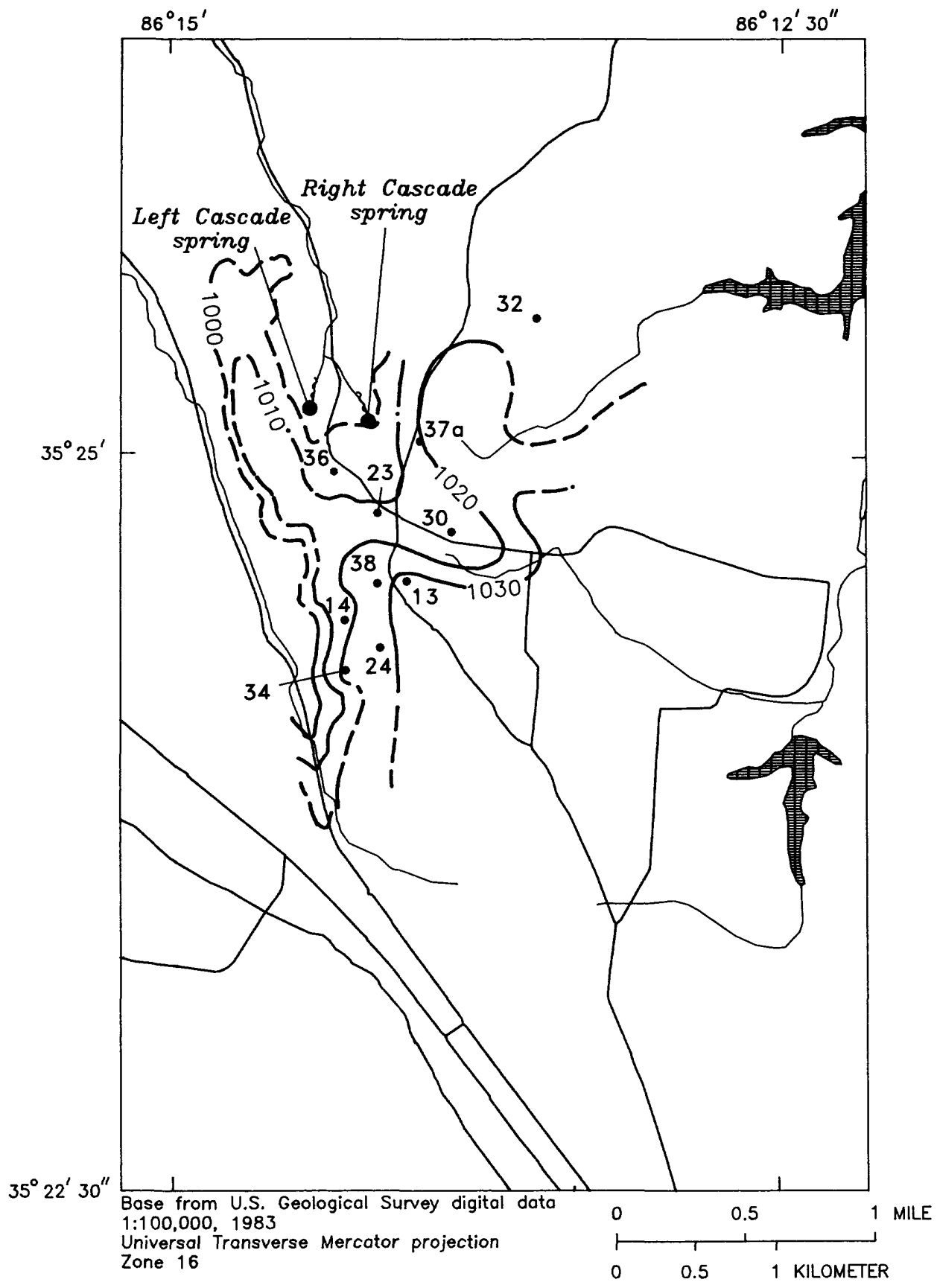

\section{EXPLANATION}

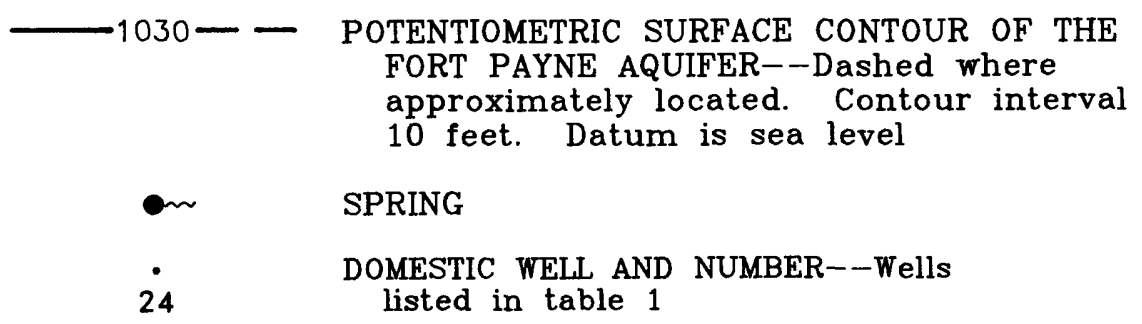

Figure 7. Potentiometric surface of the Fort Payne aquifer for April 1992. 
Manchester aquifer. Such vertical resistance would create significantly higher potentiometric heads in the Manchester aquifer.

No significant differences in water levels were observed between February and April 1992, but an average 4-foot difference was observed for the same wells between October 1991 and both February and April 1992. The greatest seasonal water-level differences were observed in wells completed in the Manchester aquifer.

The recharge area boundary for the Manchester aquifer was estimated from the groundwater divides determined from the potentiometric surface map. The estimated Cascade Springs recharge area for the Manchester aquifer encompasses approximately $1 \mathrm{mi}^{2}$. Because of limited potentiometric data, the recharge area for the Fort Payne aquifer cannot be delineated.

The extent of the recharge area for a spring with a known discharge can be estimated using assigned recharge rates for the area. Spring flow measurements for Cascade Springs, however, are severely limited. For the purpose of estimating the Cascade Springs recharge area, the 1933 combined flow measurement of $3.34 \mathrm{ft}^{3} / \mathrm{s}$ (approximately $1,500 \mathrm{gal} / \mathrm{min}$ ) was used. Based on a range of recharge rates from 6 to $10 \mathrm{in} / \mathrm{yr}$ (Hoos, 1990), the recharge area should encompass between 4.5 and $7.6 \mathrm{mi}^{2}$. These computations imply that the recharge boundary for the Manchester aquifer delineated here represents only a part of the actual recharge area for Cascade Springs. Additional recharge could be occurring farther to the south through the Fort Payne aquifer. To delineate accurately the entire recharge area, additional wells, seepage run data, and improved spring discharge measurements are required.

\section{Water Quality}

Three water-quality samples were collected at Left Cascade Spring from 1975 to 1990.

These were analyzed for major ionic constituents and physical properties, and two samples were also analyzed for volatile organic compounds (table 2). No additional water samples were collected for this investigation.

General measures of water quality include specific conductance, dissolved solids, alkalinity, and hardness. Specific conductance of Left Cascade Spring ranged from 80 to $87 \mu \mathrm{S} / \mathrm{cm}$, and dissolved solids ranged from 36 to 48 milligrams per liter (mg/L). At Arnold Air Force Base (AAFB), the median value for specific conductance in the Manchester aquifer was $87 \mu \mathrm{S} / \mathrm{cm}$ compared to $1,635 \mu \mathrm{S} / \mathrm{cm}$ in the Fort Payne aquifer. The median values for dissolved solids in the Manchester and Fort Payne aquifers at AAFB were $48 \mathrm{mg} / \mathrm{L}$ and $1,235 \mathrm{mg} / \mathrm{L}$, respectively (Haugh and others, 1992). Alkalinity of the Left Cascade Spring samples ranged from 30 to $32 \mathrm{mg} / \mathrm{L}$ as calcium carbonate, and hardness ranged from 36 to $41 \mathrm{mg} / \mathrm{L}$ as calcium carbonate. On the Highland Rim, water from the chert residuum of the Manchester aquifer typically ranges from 10 to $50 \mathrm{mg} / \mathrm{L}$ in hardness; yet, hardness can approach $350 \mathrm{mg} / \mathrm{L}$ or more in water from the Fort Payne aquifer (Burchett, 1977).

The water quality of Left Cascade Spring implies that most of the spring flow is derived from the Manchester aquifer. However, significant spring discharge from the Fort Payne aquifer is suspected on the basis of potentiometric heads. In the Cascade Springs study area, ground-water circulation through fractures of the Fort Payne aquifer could be rapid enough to minimize dissolution. Also, near the Highland Rim escarpment, the Fort Payne Formation is highly weathered, and the soluble part of the Fort Payne aquifer could be mostly dissolved. Extensive chemical weathering would leave only insoluble chert beds in the Fort Payne aquifer, forming an aquifer matrix similar to the Manchester aquifer.

Overall, the spring water contains predominantly calcium and bicarbonate ions. The samples contained low concentrations of most inorganic constituents, including nitrogen, phosphorous, and trace metals. Of the inorganic constituents and properties for which the Tennessee Department of Environment and Conservation 
Table 2. Water-quality data for Left Cascade Spring near Tullahoma, Tennessee

$[\mu \mathrm{S} / \mathrm{cm}$, microsiemens per centimeter; deg. C, degrees Celsius; $\mathrm{mg} / \mathrm{L}$, milligrams per liter; $\mu \mathrm{g} / \mathrm{L}$, micrograms per liter; wat wh tot fet, water whole fixed endpoint titration; wat wh tot it, water whole incremental titration; cols./ml, colonies per 100 milliliters; --, no data; $<$, less than; $K$, non-ideal count]

\begin{tabular}{|c|c|c|c|c|c|c|c|c|c|c|c|c|}
\hline \multirow{2}{*}{$\begin{array}{l}\text { Date } \\
\overline{02-13-75}\end{array}$} & \multirow[t]{2}{*}{$\begin{array}{c}\begin{array}{c}\text { Spec- } \\
\text { ific } \\
\text { con- } \\
\text { duct- } \\
\text { ance } \\
(\mu S / c m)\end{array} \\
80\end{array}$} & \multirow[t]{2}{*}{$\begin{array}{c}\text { pH } \\
\text { water } \\
\text { whole } \\
\text { field } \\
\text { (stand- } \\
\text { ard } \\
\text { units) }\end{array}$} & $\begin{array}{c}\text { Temper- } \\
\text { ature } \\
\text { water } \\
\text { (deg C) }\end{array}$ & \multicolumn{2}{|c|}{$\begin{array}{c}\text { Hard- } \\
\text { ness } \\
\text { total } \\
\text { (mg/L } \\
\text { as } \\
\text { ICaCO }_{3}\end{array}$} & \multirow[t]{2}{*}{$\begin{array}{c}\text { Alka- } \\
\text { linity, } \\
\text { wat wh } \\
\text { total fet, } \\
\text { field } \\
\text { (mg/L as } \\
\mathrm{CaCO}_{3} \\
30\end{array}$} & $\begin{array}{l}\text { Alka- } \\
\text { linity, } \\
\text { wat wh } \\
\text { tot it, } \\
\text { field } \\
\text { (mg/L as } \\
\left.\mathrm{CaCO}_{3}\right)\end{array}$ & $\begin{array}{c}\text { Coli- } \\
\text { form, } \\
\text { fecal, } \\
\text { (cols./ } \\
100 \mathrm{ml} \text { ) }\end{array}$ & $\begin{array}{c}\text { Strep- } \\
\text { tococci } \\
\text { fecal, } \\
\text { (cols./ } \\
100 \mathrm{ml} \text { ) }\end{array}$ & $\begin{array}{c}\text { Calcium, } \\
\text { dis- } \\
\text { solved } \\
\text { (mg/L } \\
\text { as Ca) }\end{array}$ & \multicolumn{2}{|c|}{$\begin{array}{l}\text { Magne- } \\
\text { sium, } \\
\text { dis- } \\
\text { solved } \\
\mathrm{mg} / \mathrm{L} \\
\text { as } \mathrm{Mgl}\end{array}$} \\
\hline & & & 14.0 & 30 & 36 & & -- & -- & - & 11 & 2.0 & \\
\hline $03-29-90$ & 80 & 6.4 & 15.0 & 36 & 6 & - & 30 & $<1$ & $<1$ & 10 & 2.6 & \\
\hline $11-06-90$ & 87 & 6.3 & 14.5 & 4 & 1 & - & 32 & $<1$ & K2 & 12 & 2.6 & \\
\hline Date & $\begin{array}{c}\text { Sodium, } \\
\text { dis- } \\
\text { solved } \\
\text { (mg/L } \\
\text { as } \mathrm{Nal}\end{array}$ & $\begin{array}{l}\text { Sodium } \\
\text { percent }\end{array}$ & $\begin{array}{l}\text { Sodium } \\
\text { ad- } \\
\text { sorp- } \\
\text { tion } \\
\text { ratio }\end{array}$ & $\begin{array}{l}\text { Potas- } \\
\text { sium. } \\
\text { dis- } \\
\text { solved } \\
\text { (mg/L } \\
\text { as K) }\end{array}$ & $\begin{array}{c}\text { Sulfate, } \\
\text { dis- } \\
\text { solved } \\
\text { (mg/L } \\
\text { as } \mathrm{SO}_{4} \text { ) }\end{array}$ & $\begin{array}{l}\text { Chlo- } \\
\text { ride, } \\
\text { dis- } \\
\text { solvad } \\
\text { (mg/L } \\
\text { as Cl) }\end{array}$ & $\begin{array}{l}\text { Fluo- } \\
\text { ride, } \\
\text { dis- } \\
\text { solved } \\
\text { (mg/L } \\
\text { as F) }\end{array}$ & $\begin{array}{l}\text { Silica, } \\
\text { dis- } \\
\text { solved } \\
\text { (mg/L } \\
\text { as } \\
\text { SiO }_{2} \text { l }\end{array}$ & $\begin{array}{c}\text { Solids, } \\
\text { residue } \\
\text { at } 180 \\
\text { deg. C } \\
\text { dis- } \\
\text { solved } \\
\text { (mg/L) }\end{array}$ & $\begin{array}{c}\text { Solids, } \\
\text { sum of } \\
\text { consti- } \\
\text { tuents, } \\
\text { dis- } \\
\text { solved } \\
\text { (mg/L) }\end{array}$ & $\begin{array}{l}\text { Nitro- } \\
\text { gen, } \\
\text { nitrite } \\
\text { total } \\
\text { (mg/L } \\
\text { as N) }\end{array}$ & $\begin{array}{l}\text { Nitro- } \\
\text { gen, } \\
\text { nitrate } \\
\text { total } \\
\text { (mg/L } \\
\text { as N) }\end{array}$ \\
\hline $02-13-75$ & 0.40 & 2 & 0.0 & $<0.10$ & 0.70 & 1.4 & $<0.10$ & 8.3 & 36 & 42 & - & 0.640 \\
\hline $03-29-90$ & 1.0 & 6 & .1 & .20 & 4.9 & 8.4 & $<.10$ & 8.4 & 42 & 53 & 0.027 & .923 \\
\hline $11-06-90$ & 1.1 & 6 & .1 & .10 & $<1.0$ & 3.3 & $<.10$ & 8.6 & 48 & -- & .003 & .905 \\
\hline Date & $\begin{array}{c}\text { Nitro- } \\
\text { gen, } \\
\text { NO2 + NO3 } \\
\text { total } \\
\text { (mg/L } \\
\text { as N) }\end{array}$ & $\begin{array}{c}\text { Nitro- } \\
\text { gen, } \\
3 \text { ammonia } \\
\text { total } \\
\text { (mg/L } \\
\text { as N) }\end{array}$ & $\begin{array}{c}\text { Nitro- } \\
\text { gen,am- } \\
\text { monia + } \\
\text { organic } \\
\text { total } \\
\text { (mg/L } \\
\text { as N) }\end{array}$ & $\begin{array}{c}\text { Phos- } \\
\text { phorus, } \\
\text { total } \\
\text { (mg/L } \\
\text { as P) }\end{array}$ & $\begin{array}{l}\text { Alum- } \\
\text { inum, } \\
\text { dis- } \\
\text { solved } \\
\text { (wg/L } \\
\text { as Al) }\end{array}$ & $\begin{array}{c}\text { Arsenic, } \\
\text { dis- } \\
\text { solved } \\
\text { (ug/L } \\
\text { as As) }\end{array}$ & $\begin{array}{l}\text { Beryl- } \\
\text { lium, } \\
\text { dis- } \\
\text { solved } \\
\text { (wg/L. } \\
\text { as Be) }\end{array}$ & $\begin{array}{l}\text { Cadmium, } \\
\text { dis- } \\
\text { solved } \\
\text { (ug/L } \\
\text { as Cd) }\end{array}$ & $\begin{array}{l}\text { Chro- } \\
\text { mium, } \\
\text { dis- } \\
\text { solved } \\
(\mu g / L \\
\text { as } \mathrm{Cr})\end{array}$ & $\begin{array}{c}\text { Copper, } \\
\text { dis- } \\
\text { solved } \\
\text { ( } \mu \mathrm{g} / \mathrm{L} \\
\text { as Cu) }\end{array}$ & $\begin{array}{l}\text { Iron, } \\
\text { dis- } \\
\text { solved } \\
(\mu \mathrm{g} / \mathrm{L} \\
\text { as Fe) }\end{array}$ & $\begin{array}{l}\text { Lead, } \\
\text { dis- } \\
\text { solved } \\
(\mu \mathrm{g} / \mathrm{L} \\
\text { as } \mathrm{Pb})\end{array}$ \\
\hline $02-13-75$ & 0.640 & - & - & 0.010 & -- & - & -- & - & - & -- & $<10$ & - \\
\hline $03-29-90$ & .950 & 0.029 & 0.30 & .013 & $<10$ & $<1$ & $<0.5$ & $<1.0$ & $<5$ & $<10$ & $<3$ & $<10$ \\
\hline $11-06-90$ & .908 & .004 & $<.20$ & .004 & $<10$ & $<1$ & $<.5$ & $<1.0$ & $<1$ & $<1$ & $<3$ & $<1$ \\
\hline Date & $\begin{array}{c}\text { Manga- } \\
\text { nese, } \\
\text { dis- } \\
\text { solved } \\
(\mu \mathrm{g} / \mathrm{L} \\
\text { as } \mathrm{Mn} \mid\end{array}$ & $\begin{array}{c}\text { Mercury, } \\
\text { dis- } \\
\text { solved } \\
(\boldsymbol{\mu g} / \mathbf{L} \\
\text { as } \mathrm{Hg})\end{array}$ & $\begin{array}{l}\text { Sele- } \\
\text { nium, } \\
\text { dis- } \\
\text { solved } \\
(\mu \mathrm{g} / \mathrm{L} \\
\text { as Se) }\end{array}$ & $\begin{array}{c}\text { Silver, } \\
\text { dis- } \\
\text { solved } \\
(\mu \mathrm{g} / \mathrm{L} \\
\text { as } \mathrm{Agl})\end{array}$ & $\begin{array}{l}\text { Stron- } \\
\text { tium, } \\
\text { dis- } \\
\text { solved } \\
(\mathrm{wg} / \mathrm{L} \\
\text { as } \mathrm{Sr})\end{array}$ & $\begin{array}{l}\text { Zinc, } \\
\text { dis- } \\
\text { solved } \\
(\mu \mathrm{g} / \mathrm{L} \\
\text { as } \mathrm{Zn})\end{array}$ & $\begin{array}{c}\text { Carbon, } \\
\text { organic } \\
\text { total } \\
\text { (mg/L } \\
\text { as C) }\end{array}$ & $\begin{array}{l}\text { Di- } \\
\text { chloro- } \\
\text { bromo- } \\
\text { methane, } \\
\text { total } \\
(\mu g / L)\end{array}$ & $\begin{array}{c}\text { Carbon- } \\
\text { tetra- } \\
\text { chlo- } \\
\text { ride, } \\
\text { total } \\
(\mu g / L)\end{array}$ & $\begin{array}{c}\text { 1,2-Di- } \\
\text { chloro- } \\
\text { ethane, } \\
\text { total } \\
(\mu \mathrm{g} / \mathrm{L})\end{array}$ & $\begin{array}{l}\text { Bromo- } \\
\text { form, } \\
\text { total } \\
(\mu \mathrm{g} / \mathrm{L})\end{array}$ & \\
\hline $02-13-75$ & 60 & - & - & - & - & - & -- & - & -- & -- & - & \\
\hline $03-29-90$ & 1 & $<0.1$ & $<1$ & 1.0 & 11 & 9 & $<0.1$ & $<0.2$ & $<0.2$ & $<0.2$ & $<0.2$ & \\
\hline $11-06-90$ & $<1$ & $<.1$ & $<1$ & $<1.0$ & 11 & 6 & .1 & -- & -- & -- & -- & \\
\hline
\end{tabular}


Table 2. Water-quality data for Left Cascade Spring near Tullahoma, Tennessee--Continued

\begin{tabular}{|c|c|c|c|c|c|c|c|c|c|c|c|}
\hline Date & $\begin{array}{c}\text { Chloro- } \\
\text { di- } \\
\text { bromo- } \\
\text { methane, } \\
\text { total } \\
(\mu g / L)\end{array}$ & $\begin{array}{l}\text { Chloro- } \\
\text { form, } \\
\text { total } \\
(\mu g / L)\end{array}$ & $\begin{array}{c}\text { Toluene, } \\
\text { total } \\
(\mu g / L)\end{array}$ & $\begin{array}{c}\text { Benzene, } \\
\text { total } \\
(\mu g / L)\end{array}$ & $\begin{array}{c}\text { Chloro- } \\
\text { benzene, } \\
\text { total } \\
(\mu g / L)\end{array}$ & $\begin{array}{c}\text { Chloro- } \\
\text { ethane, } \\
\text { total } \\
(\mu g / L)\end{array}$ & $\begin{array}{c}\text { Ethyl- } \\
\text { benzene, } \\
\text { total } \\
(\mu g / L)\end{array}$ & $\begin{array}{c}\text { Methyl- } \\
\text { bromide, } \\
\text { total } \\
(\mu g / L)\end{array}$ & $\begin{array}{c}\text { Methyl- } \\
\text { chlo- } \\
\text { ride, } \\
\text { total } \\
(\mu g / L)\end{array}$ & $\begin{array}{l}\text { Methyl- } \\
\text { ene } \\
\text { chlo- } \\
\text { ride, } \\
\text { total } \\
(\mu g / L)\end{array}$ & $\begin{array}{l}\text { Tetra- } \\
\text { chloro- } \\
\text { ethyl- } \\
\text { ene, } \\
\text { total } \\
(\mu g / L)\end{array}$ \\
\hline $02-13-75$ & -- & -- & -- & -- & - & -- & -- & - & -- & - & - \\
\hline $03-29-90$ & $<0.2$ & $<0.2$ & $<0.2$ & $<0.2$ & $<0.20$ & $<0.2$ & $<0.2$ & $<0.2$ & $<0.2$ & $<0.2$ & $<0.2$ \\
\hline $11-06-90$ & - & - & - & -- & - & -- & -- & - & -- & -- & -- \\
\hline Date & $\begin{array}{c}\text { Tri- } \\
\text { chloro- } \\
\text { fluoro- } \\
\text { methane, } \\
\text { total } \\
(\mu \mathrm{g} / \mathrm{L})\end{array}$ & $\begin{array}{c}\text { 1.1-Di- } \\
\text { chloro- } \\
\text { ethane, } \\
\text { total } \\
(\mu \mathrm{g} / \mathrm{L})\end{array}$ & $\begin{array}{l}\text { 1.1-Di- } \\
\text { chloro- } \\
\text { ethyl- } \\
\text { ene, } \\
\text { total } \\
(\mu \mathrm{g} / \mathrm{L})\end{array}$ & $\begin{array}{c}1,1,1- \\
\text { Tri- } \\
\text { chloro- } \\
\text { ethane, } \\
\text { total } \\
(\mu \mathrm{g} / \mathrm{L})\end{array}$ & $\begin{array}{c}\text { 1,1,2- } \\
\text { Tri- } \\
\text { chloro- } \\
\text { ethane, } \\
\text { total } \\
(\mu \mathrm{g} / \mathrm{L})\end{array}$ & $\begin{array}{c}1,1,2,2 \\
\text { Tetra- } \\
\text { chloro- } \\
\text { ethane, } \\
\text { total } \\
(\mu \mathrm{g} / \mathrm{L})\end{array}$ & $\begin{array}{c}\text { 1,2-Di- } \\
\text { chloro- } \\
\text { benzene, } \\
\text { total } \\
(\mu \mathrm{g} / \mathrm{L})\end{array}$ & $\begin{array}{c}\text { 1,2-Di- } \\
\text { chloro- } \\
\text { propane, } \\
\text { total } \\
(\mu \mathrm{g} / \mathrm{L})\end{array}$ & $\begin{array}{c}1,2- \\
\text { Transdi } \\
\text { chloro- } \\
\text { ethene, } \\
\text { total } \\
(\mu \mathrm{g} / \mathrm{L})\end{array}$ & $\begin{array}{c}\text { 1,3-Di- } \\
\text { chloro- } \\
\text { propene, } \\
\text { total } \\
(\mu \mathrm{g} / \mathrm{L})\end{array}$ & $\begin{array}{c}\text { 1,3-Di- } \\
\text { chloro- } \\
\text { benzene, } \\
\text { total } \\
(\mu \mathrm{g} / \mathrm{L})\end{array}$ \\
\hline $02-13-75$ & - & - & - & - & -- & - & -- & - & 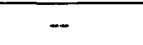 & -- & - \\
\hline $03-29-90$ & $<0.2$ & $<0.2$ & $<0.2$ & $<0.2$ & $<0.2$ & $<0.2$ & $<0.20$ & $<0.2$ & 1.3 & $<0.20$ & $<0.20$ \\
\hline $11-06-90$ & - & -- & -- & - & -- & -- & $<5.0$ & -- & - & - & $<5.0$ \\
\hline Date & $\begin{array}{c}\text { 1,4-Di- } \\
\text { chloro- } \\
\text { benzene, } \\
\text { total } \\
(\mu \mathrm{g} / \mathrm{L})\end{array}$ & $\begin{array}{c}2- \\
\text { Chloro- } \\
\text { ethyl- } \\
\text { vinyl- } \\
\text { ether, } \\
\text { total } \\
\text { (wg/L) }\end{array}$ & $\begin{array}{c}\text { Di- } \\
\text { chloro- } \\
\text { di- } \\
\text { fluoro- } \\
\text { methane, } \\
\text { total } \\
\text { (wg/L) }\end{array}$ & $\begin{array}{l}\text { Trans- } \\
\text { 1,3-di- } \\
\text { chloro- } \\
\text { propene, } \\
\text { total } \\
\text { (wg/L) }\end{array}$ & $\begin{array}{c}\text { Cis } \\
\text { 1,3-di- } \\
\text { chloro- } \\
\text { propene, } \\
\text { total } \\
(\mu \mathrm{g} / \mathrm{L})\end{array}$ & $\begin{array}{l}\text { Vinyl } \\
\text { chlo- } \\
\text { ride, } \\
\text { total } \\
\text { (wg/L) }\end{array}$ & $\begin{array}{l}\text { Tri- } \\
\text { chloro- } \\
\text { ethyl- } \\
\text { ene, } \\
\text { total } \\
(\mu \mathrm{g} / \mathrm{L})\end{array}$ & $\begin{array}{c}\text { Styrene, } \\
\text { total } \\
(\mu \mathrm{g} / \mathrm{L})\end{array}$ & $\begin{array}{c}1,2- \\
\text { Dibromo- } \\
\text { ethane, } \\
\text { water } \\
\text { whole } \\
\text { total } \\
(\mu \mathrm{g} / \mathrm{L})\end{array}$ & $\begin{array}{c}\text { Xylene, } \\
\text { total } \\
\text { water } \\
\text { whole } \\
\text { total } \\
(\mu \mathrm{g} / \mathrm{L})\end{array}$ & $\begin{array}{l}\text { Methyl- } \\
\text { lene } \\
\text { blue } \\
\text { active } \\
\text { sub- } \\
\text { stance } \\
\text { (mg/L) }\end{array}$ \\
\hline $02-13-75$ & - & - & - & -- & - & -- & -- & - & -- & -- & -- \\
\hline $03-29-90$ & $<0.20$ & $<0.2$ & $<0.2$ & $<0.2$ & $<0.2$ & $<0.2$ & 0.2 & $<0.2$ & $<0.2$ & $<0.20$ & 0.01 \\
\hline $11-06-90$ & $<5.0$ & -- & -- & -- & -- & -- & - & -- & -- & - & .03 \\
\hline
\end{tabular}

(1991) has established primary or secondary drinking water standards, only $\mathrm{pH}$ and manganese sometimes exceeded the recommended limits in the raw water samples. The $\mathrm{pH}$ of the spring water ranged from 6.1 to 6.4 units, and manganese was detected at levels between less than 1 and 60 micrograms per liter $(\mu \mathrm{g} / \mathrm{L})$.

The most recent water-quality analyses detected small amounts of two volatile organic compounds: $1.3 \mu \mathrm{g} / \mathrm{L}$ of 1,2-transdichloroethene and $0.2 \mu \mathrm{g} / \mathrm{L}$ trichloroethylene. These concentrations are below the U.S. Environmental Protection Agency maximum contaminant limits for drinking water of $100 \mu \mathrm{g} / \mathrm{L} \mathrm{1,2-transdichloro-}$ ethene and $5 \mu \mathrm{g} / \mathrm{L}$ trichloroethylene. More sampling is required, however, to confirm the continued presence of contaminants and to evaluate any changing conditions.

\section{SUMMARY}

Cascade Springs, two large springs of roughly equal discharge, are located on the escarpment of the Highland Rim immediately above the Chattanooga Shale. The town of Wartrace relies upon Left Cascade Spring as its sole source of water.

Ground-water flow in the study area is influenced by characteristics of the Manchester and the Fort Payne aquifers. The Manchester aquifer 
consists of a zone of well-sorted, unconsolidated chert gravel with minimal clay content and the upper, well-fractured interval of the Fort Payne Formation. It is a highly productive aquifer that supplies water to most domestic wells in the study area. The Fort Payne aquifer consists of dense, cherty limestone. Ground-water flow in the Fort Payne aquifer occurs through fractures and solution-enlarged horizontal bedding planes just above the Chattanooga Shale. The Fort Payne aquifer is recharged by the Manchester aquifer. In poorly fractured areas where the dense, cherty limestone of the Fort Payne Formation impedes the downward flow of ground water from the Manchester aquifer, large potentiometric head differences between the two aquifers can occur. The Fort Payne aquifer discharges through springs along the Highland Rim escarpment.

Two potentiometric-surface maps based on April 1992 water-level data were constructed to determine the directions of ground-water flow and to delineate the recharge areas for the Manchester and the Fort Payne aquifers. According to these maps, recharge to Cascade Springs occurs primarily to the southeast of the springs.
The recharge area for the Manchester aquifer occupies approximately 1 square mile. Assigned local recharge rates and available spring discharge measurements imply that the delineated recharge area for the Manchester aquifer is of insufficient extent to supply the total flow of Cascade Springs. Because of the limited number of wells completed in the Fort Payne aquifer, the recharge area for the Fort Payne aquifer cannot be delineated. Additional recharge can be occurring through the Fort Payne aquifer south of the delineated recharge area for the Manchester aquifer. Additional data would be necessary to determine the Fort Payne aquifer recharge boundary.

Recent water-quality analyses of Left Cascade Spring showed low concentrations of inorganic constituents and dissolved solids, typical of ground water from the Manchester aquifer. Similar ground-water quality can result from the highly weathered intervals of the Fort Payne aquifer where ground water has been in contact with mostly insoluble aquifer materials. Two volatile organic compounds $(1.3 \mu \mathrm{g} / \mathrm{L}$ of 1,2-transdichloroethene and $0.2 \mu \mathrm{g} / \mathrm{L}$ of trichloroethylene) were detected. 


\section{SELECTED REFERENCES}

Brahana, J.V., and Bradley, M.W., 1986, Preliminary delineation and description of the regional aquifers of Tennessee--The Highland Rim aquifer system: U.S. Geological Survey WaterResources Investigations Report 82-4054, 38 p.

Burchett, C.R., 1977, Water resources of the upper Duck River basin, central Tennessee: Tennessee Division of Water, Water Resources Series no. $12,103 \mathrm{p}$.

Haugh, C.J., and Mahoney, E.N., 1994, Hydrogeology and simulation of ground-water flow at Arnold Air Force Base, Coffee and Franklin Counties, Tennessee: U.S. Geological Survey Water-Resources Investigations Report 93-4207, $69 \mathrm{p}$.

Haugh, C.J., Mahoney E.N., and Robinson, J.A., 1992, Well-construction, water-level, geophysical, and water-quality data for ground-water monitoring wells for Arnold Air Force Base, Tennessee: U.S. Geological Survey Open-File Report 92-135, $88 \mathrm{p}$.

Hem, J.D., 1985, Study and interpretation of the chemical characteristics of natural water (3rd ed.): U.S. Geological Survey Water-Supply Paper 2254, $263 \mathrm{p}$.

Hoos, A.B., 1990, Recharge rates and aquifer hydraulic characteristics for selected drainage basins in Middle and East Tennessee: U.S. Geological Survey Water-Resources Investigations Report 90-4015, 34 p.
Hutson, S.S., 1991, Ground-water use by publicsupply systems in Tennessee in 1988: U.S. Geological Survey Open-File Report 91-176, $1 \mathrm{p}$.

National Oceanic and Atmospheric Administration, 1980, Climatological data, Tennessee: Asheville, North Carolina, U.S. Department of Commerce, National Climatic Data Center, 14 p.

Smith, Ollie, Jr., 1962, Ground-water resources and municipal water supplies of the Highland Rim in Tennessee: Tennessee Department of Conservation and Commerce, Division of Water

Resources, Water Resources Series no. 3, 237 p.

Tennessee Department of Environment and Conservation, 1991, Regulations for public water systems and drinking water quality: Division of Water Suppply, chapt. 1200-5-1, 103 p.

Theis, C.V., 1936, Ground water in south-central Tennessee: U.S. Geological Survey WaterSupply Paper 677, $182 \mathrm{p}$.

Wilson, R.L., 1970a, Geologic map and mineral resources summary of the Normandy quadrangle, Tennessee: Tennessee Department of Conservation, Division of Geology Map GM 79-NE and MRS 79-NE, scale 1:24,000. 1970b, Geologic map and mineral resources summary of the Ovoca quadrangle, Tennessee: Tennessee Department of Conservation, Division of Geology Map GM 86-NW and MRS 86-NW, scale $1: 24,000$.

Zurawski, Ann, 1978, Summary appraisals of the Nation's ground-water resources--Tennessee Region: U.S. Geological Survey Professional Paper 813-L, 35 p. 